\title{
UPAYA PENINGKATAN KEMAMPUAN KOMUNIKASI MATEMATIS SISWA DENGAN MODEL PEMBELAJARAN KOOPERATIF DI SMP N 2 SEDAYU YOGYAKARTA
}

\author{
Dhian Arista Istikomah \\ FKIP Universitas PGRI Yogyakarta \\ E-mail: dhian.arista@gmail.com
}

\begin{abstract}
Abstrak
Penelitian ini bertujuan untuk meningkatkan kemampuan komunikasi matematika siswa pada mata pelajaran matematika materi pokok kubus dan balok dalam pokok bahasan luas permukaan dan volume melalui model pembelajaran kooperatif. Penelitian ini adalah penelitian tindakan kelas dengan subjek penelitian adalah siswa kelas VIIIE SMP N 2 Sedayu semester genap tahun ajaran 2012/2013. Penelitian ini terdiri dari dua siklus, siklus pertama dilaksanakan dalam 3 pertemuan dan siklus kedua dilaksanakan dalam 3 pertemuan. Teknik pengumpulan data menggunakan observasi, tes kemampuan komunikasi matematika siswa, wawancara dan catatan lapangan. Analisis data yang digunakan yaitu, analisis observasi siswa dan analisis tes kemampuan komunikasi matematika dengan analisis persentase. Hasil penelitian menyimpulkan bahwa (1) pembelajaran dengan model pembelajaran kooperatif dapat meningkatkan kemampuan komunikasi matematika siswa dengan persentase hasil observasi kegiatan siswa sebesar 68,6\% pada siklus I menjadi 86,9\% pada siklus II. (2) pembelajaran dengan model pembelajaran kooperatif dapat meningkatkan kemampuan komunikasi matematika siswa dari nilai rata-rata kelas awal sebelum tindakan sebesar 41,63 dengan ketuntasan prasiklus sebesar 9\% (kualifikasi kurang) menjadi nilai rata-rata kelas sebesar 79,81 dengan ketuntasan kelas sebesar 81,8\% (kualifikasi tinggi) pada siklus I, nilai rata-rata kelas sebesar 84,9 dengan ketuntasan kelas sebesar 90,9\% (kualifikasi tinggi) pada siklus II.
\end{abstract}

Kata kunci : Model Pembelajaran Kooperatif, Kemampuan komunikasi matematis

PENDAHULUAN

Pemahaman matematis erat kaitannya dengan komunikasi matematis. Siswa yang mempunyai kemampuan pemahaman matematis dituntut juga untuk dapat mengkomunikasikan pemahaman tersebut agar dapat dimanfaatkan oleh orang lain. Melalui kemampuan komunikasi matematis siswa juga dapat memanfaatkan konsep-konsep matematika yang sudah dipahami orang lain. Dengan mengkomunikasikan ideide matematis tersebut kepada orang lain, seseorang bisa meningkatkan pemahaman matematisnya. Matematika adalah bahasa 
simbol dimana setiap orang yang belajar matematika dituntut untuk mempunyai kemampuan untuk berkomunikasi dengan menggunakan bahasa simbol tersebut. Kemampuan komunikasi matematis akan membuat seseorang bisa memanfaatkan matematika untuk kepentingan diri sendiri maupun orang lain, sehingga akan meningkatkan sikap positif terhadap matematika baik dari dalam diri sendiri maupun orang lain.

Kemampuan komunikasi matematis menunjang kemampuankemampuan matematis yang lain, misalnya kemampuan pemecahan masalah. Dengan kemampuan komunikasi yang baik maka suatu masalah akan lebih cepat bisa direpresentasikan dengan benar dan hal ini akan mendukung untuk penyelesaian masalah.

Mengingat begitu pentingnya komunikasi matematis dalam pembelajaran matematika, peneliti membuat suatu kajian tentang hal ini dimana subjek penelitian adalah siswa SMPN 2 Sedayu.

Kemampuan komunikasi matematis siswa SMPN 2 Sedayu masih sangat kurang. Informasi ini diperoleh dari kegiatan observasi yang dilakukan oleh peneliti. Dari data observasi, didapatkan informasi kemampuan komunikasi matematis siswa masih kurang. Hal ini ditunjukkan dengan ketika guru bertanya tentang suatu materi, siswa tidak berani mengemukakan pendapatnya. Ketika diadakan wawancara diluar kelas terkait hal tersebut, siswa mengaku tidak berani mengemukakan pendapatnya, merasa khawatir jika keliru. Ketika siswa diberi pertanyaan terkait materi yang disajikan dalam bentuk gambar ataupun diagram, siswa tidak dapat menterjemahkan infoinfo dalam gambar atau grafik tersebut. Pada saat guru memberikan latihan soal dalam bentuk soal cerita, siswa masih kesulitan dalam mengerjakan latihan soal. Sebagian besar siswa ketika dihadapkan pada soal cerita, siswa tidak kesulitan dalam menentukan informasiinformasi penting dalam soal cerita tersebut.

\section{Permasalahan-permasalahan}

tersebut, peneliti simpulkan bahwa siswa masih mengalami kesulitan dalam komunikasi matematis.

Proses pembelajaran dikelas, guru menerapkan model pembelajaran konvensional, dimana guru sebagai aktor utama dalam pembelajaran. Aktifitas antar siswa dirasa kurang, sehingga perilaku terkait pengkomunikasian gagasan atau ide pemikiran masih sangat kurang. Hal ini menjadi pendukung kurangnya kemampuan komunikasi siswa. Oleh karena itu peneliti mencoba menerapkan model pembelajaran kooperatif dalam pembelajaran di kelas VIIIE SMP N 2 Sedayu. Dan pada akhir penerapan model pembelajaran tersebut, 
akan dilihat peningkatan kemampuan komunikasi matematis.

\section{KAJIAN TEORI}

\section{a. Komunikasi Matematis}

Menurut Utari Sumarno dalam Yani Ramdani (2012: 48), indikator dari kemampuan komunikasi matematis adalah :

a. Menghubungkan benda nyata, gambar, dan diagram ke dalam ide matematika.

b. Menjelaskan ide, situasi, dan relasi matematika secara lisan atau tulisan, dengan benda nyata, gambar, grafik, dan aljabar.

c. Menyatakan peristiwa sehari-hari dalam bahasa dan simbol matematika.

d. Mendengarkan, berdiskusi, dan menulis tentang matematika.

e. Membaca presentasi matematika tertulis dan menyusun pertanyaan yang relevan

Indikator yang digunakan peneliti dimodifikasi dari Utari Sumarno dalam Yani Ramdani (2012: 48) adalah sebagai berikut:

a. Kemampuan siswa menghubungkan benda nyata, gambar, dan diagram ke dalam ide matematika

b. Kemampuan siswa menjelaskan ide matematika dengan gambar atau benda nyata secara lisan dan tertulis c. Kemampuan siswa mengubah soal cerita kedalam bahasa dan simbol matematika

d. Kemampuan siswa membuat pertanyaan matematika

Dalam penelitian ini yang dimaksud dengan kemampuan komunikasi matematika merupakan kemampuan yang dimiliki siswa untuk menghubungkan konsep matematika, menjelaskan ide matematika, mengubah soal cerita ke dalam bahasa matematika dan kemampuan siswa membuat pertanyaaan serta membuat jawabannya.

\section{b. Model Pembelajaran Kooperatif}

Pembelajaran kooperatif adalah model pembelajaran yang menekankan kerjasama siswa dalam kelompok kecil yang beranggotakan empat orang untuk menguasai materi pembelajaran yang disampaikan oleh guru (Slavin, 2008:8).

Anita Lie (2008:32-35) menyatakan bahwa ada lima unsur model pembelajaran kooperatif, meliputi :

(1) Saling ketergantungan positif

(2) Tanggung jawab perseorangan

(3) Tatap muka

(4) Komunikasi antara anggota

(5) Evaluasi proses kelompok

\section{METODE PENELITIAN}

Penelitian ini dirancang dengan menggunakan penelitian tindakan kelas dengan subyek penelitian siswa kelas VIIIE SMP N 2 Sedayu yang berjumlah 
24 siswa dan obyek penelitian ini adalah pelaksanaan pembelajaran matematika untuk meningkatkan kemampuan komunikasi matematika dengan menggunakan model pembelajaran kooperatif.

Desain penelitian yang digunakan adalah Penelitian Tindakan Kelas (PTK) menurut Arikunto, dkk (2008: 16) dan dapat dilihat dalam alur pelaksanaan PTK pada gambar berikut.

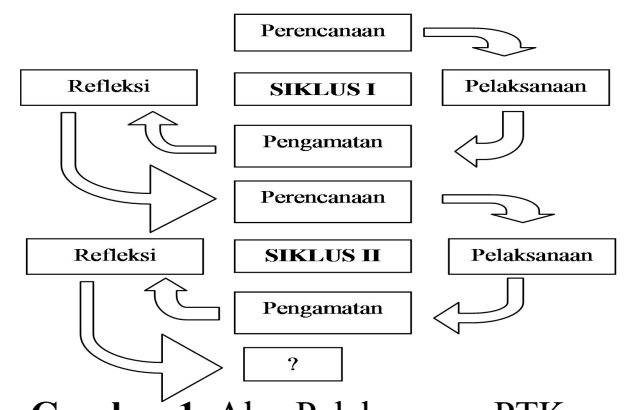

Gambar 1. Alur Pelaksanaan PTK

Penelitian ini terdiri atas 2 siklus, masing-masing siklus melalui tahap perencanaan, pelaksanaan tindakan, pengamatan terhadap pelaksanaan tindakan dan refleksi. Setiap kegiatan pembelajaran.

Berikut deskripsi kegiatan siklus:

\section{Perencanaan (Planning)}

Pada tahap perencanaan diawali dengan merancang tindakan yang akan dilakukan antara lain:

a. Peneliti dan guru mempersiapkan materi yang akan diajarkan.

b. Peneliti menyusun rencana pelaksanaan pembelajaran (RPP) yang sesuai dengan langah- langkah model pembelajaran kooperatif.

c. Menyusun dan mempersiapkan pedoman lembar observasi, dan pedoman wawancara

d. Menyusun dan mempersiapkan sarana dan media pembelajaran yang akan digunakan seperti LKS

e. Peneliti mempersiapkan soal-soal latihan dan soal-soal untuk tes tiap siklus.

\section{Pelaksanaan Tindakan (acting)}

Pada tahap pelaksanaan tindakan, guru melaksanakan pembelajaran melalui model pembelajaran kooperatif yang telah direncanakan sebelumnya.

\section{Pengamatan (Observing)}

Kegiatan pengamatan ini dilakukan bersamaan dengan pelaksanaan tindakan sebagai upaya untuk mengetahui proses pembelajaran.

\section{Refleksi (Reflekting)}

Refleksi dilakukan berdasarkan hasil observasi yaitu merenungkan dan memikirkan tindakan yang telah dilakukan untuk memperoleh perbaikan dan mengontrol jalannya penelitian agar berjalan sesuai dengan tujuan penelitian.

Dari hasil observasi dianalisis dan didiskusikan dengan guru untuk mengetahui kekurangan-kekurangan sehingga segera dilakukan perbaikan untuk perencanaan tindakan pada siklus berikutnya. Jika masalah belum teratasi maka akan dilakukan perencanaan 
ulang, tindakan baru, observasi, refleksi kembali yang nantinya akan disebut siklus 2 dan seterusnya. Siklus dihentikan apabila data yang ditampilkan siswa sudah jenuh atau kondisi kelas dalam pembelajaran sudah stabil.

\section{HASIL DAN PEMBAHASAN}

Kegiatan penelitian ini dilaksanakan dalam 2 siklus. Deskripsi pelaksanaan tiap siklus dapat dilihat dari pemaparan berikut:

\section{Siklus I}

\section{a. Perencanaan (Planning)}

Pada tahap ini, peneliti menyiapkan rencana pembelajaran dengan menggunakan model pembelajaran kooperatif yang selanjutnya didiskusikan dengan guru. Instrument yang disiapkan untuk proses pembelajaran pada tahap ini adalah sebagai berikut:

1) Rencana pelaksanaan pembelajaran (RPP) yang berisi langkah-langkah pelaksanaan kegiatan pembelajaran menggunakan model pembelajaran kooperatif yang akan dilakukan pada setiap pertemuan.

2) LKS matematika dengan submateri :
a) Menentukan rumus dan menghitung luas permukaan kubus (LKS 1)
b) Menentukan rumus dan menghitung volume kubus (LKS 2)

3) Latihan Soal

a) Menentukan rumus dan menghitung luas permukaan kubus

b) Menentukan rumus dan menghitung volume kubus

4) Soal tes siklus 1

5) Lembar observasi guru

6) Lembar observasi aktivitas siswa

7) Catatan Lapangan

\section{b. Pelaksanaan}

Siklus I dalam penelitian ini dilaksanakan dalam tiga kali pertemuan.

1) Pertemuan Pertama

Pertemuan pertama dilaksanakan pada hari Selasa tanggal 14 Mei 2013. Pada awalnya guru membuka pembelajaran dengan berdoa dan mengucapkan salam. Guru menjelaskan model pembelajaran yang akan digunakan. Guru membacakan hasil pembagian kelompok dan meminta siswa untuk duduk pada kelompoknya masing-masing. Selanjutnya guru dan observer membagikan 2 bendel lks 1 kepada setiap kelompok dan diberikan waktu 30 menit. Kegiatan diskusi dilanjutkan hingga masing-masing kelompok dapat membuat membuat pertanyaan, menyimpulkan dan menyelesaikan soalnya. Setelah sekiranya cukup, guru dan mengarahkan siswa untuk mepresentasikan hasil diskusinya. Guru memanggil kelompok 1 untuk mempresentasikan kegiatan 1. Setelah 
itu guru membahas pekerjaan dari kelompok yang sudah menuliskan hasil diskusi mereka dan meminta pendapat dari kelompok lain. Selanjutnya guru memanggil kelompok 2 untuk mempresentasikan kegiatan 2. Setelah itu guru membahas pekerjaan dari kelompok yang sudah menuliskan hasil diskusi mereka dan meminta pendapat dari kelompok lain sampai dengan lks 4 dikerjakan oleh kelompok 4. Guru kemudian melakukan evaluasi dan penyimpulan terhadap materi hari ini.

Setelah pembelajaran berakir, guru meminta siswa untuk mempelajari materi selanjutnya kemudian guru menutup pembelajaran dengan berdo'a dan mengucapkan salam.

2) Pertemuan Kedua

Pelaksanaan pertemuan kedua sama seperti pertemuan pertama. Terdapat kemajuan di pertemuan ini, diantaranya, suasana kelas terlihat lebih tenang dari pertemuan pertama karena siswa sudah mulai dapat berdiskusi dengan teman satu kelompoknya. Guru berkeliling mendorong diskusi antar siswa dalam kelompok dan memberikan arahan serta bimbingan bagi siswa atau kelompok yang mengalami kesulitan dalam menyelesaikan LKS.

Kemudian guru menutup pembelajaran dengan berdo'a dan mengucapkan salam.

\section{3) Pertemuan Ketiga}

Pertemuan ini dilaksanakan tes siklus 1 yang diadakan selama 40 menit. Guru meminta siswa untuk menyimpan buku matematika.

\section{c. Pengamatan (Observing)}

1) Data Hasil Observasi Guru

Berdasarkan hasil observasi guru, guru telah melakukan langkahlangkah pembelajaran dengan menggunakan model pembelajaran kooperatif dengan cukup baik, tetapi ada beberapa tahapan pembelajaran belum dilakukan. Pada pertemuan pertama, guru belum menyampaikan tujuan pembelajaran, dan guru belum membimbing dan mengarahkan salah satu kelompok untuk menjadi pemimpin diskusi kelompok. Pada pertemuan kedua guru juga belum megarahkan salah satu siswa dalam kelompok untuk menjadi pemimpin diskusi kelompok.

\section{2) Data Hasil Observasi Siswa}

Dari hasil pengamatan yang dilakukan oleh observer pada proses pembelajaran dengan menggunakan model pembelajaran kooperatif pada siklus 1. Pengamatan yang dilakukan adalah tiap individu dalam kelompok. Pada awal pertemuan siswa masih merasa canggung untuk berdiskusi karena belum terbiasa dengan metode yang digunakan. Akan tetapi lamakelamaan siswa sudah mulai terbiasa dengan metode yang digunakan. Sebagian besar siswa telah melakukan 
kegiatan sesuai tahapan model pembelajaran. Hanya saja masih ada beberapa siswa yang melakukan kegiatan yang tidak relevan dengan pembelajaran.

\section{3) Data Catatan Lapangan}

Menurut hasil data catatan lapangan masih ada beberapa siswa yang belum terlibat aktif dalam proses pembelajaran yang dilaksanakan. Beberapa siswa asyik mengobrol bersama temannya dan kurang aktif dalam menjawab pertanyaan yang diberikan oleh guru. Dalam berdiskusi kerjasama dalam kelompok masih kurang aktif karena masih ada beberapa siswa yang acuh dan tidak ikut mengerjakan LKS.

\section{4) Data Hasil Wawancara}

Berdasarkan data hasil wawancara dengan guru dan siswa, menunjukkan bahwa guru dan siswa merasa senang menggunakan model pembelajaran kooperatif akan tetapi masih ada kendala yang dihadapi. Diantaranya adalah siswa masih kurang berpartisipasi dalam kegiatan diskusi dan masih merasa canggung dalam berpendapat. Akan tetapi model pembelajaran ini bagus untuk meningkatkan kemampuan komunikasi siswa, karena dengan belajar dalam kelompok siswa tidak akan canggung mengeluarkan pendapat dan ide mereka.

\section{d. Refleksi}

Dalam tahap ini, peneliti dan guru matematika melakukan refleksi bersama atas tindakan yang telah dilakukan selama siklus I. Peneliti dan guru kemudian meninjau kembali apakah ada perubahan aspek yang diamati, seberapa jauh tindakan telah sesuai dengan rencana, bagaimana hasilnya, apa hambatan-hambatannya, serta langkah apa yang harus dilakukan pada siklus berikutnya.

Berdasarkan pengamatan selama proses pembelajaran dengan menggunakan model pembelajaran kooperatif yang telah dilaksanakan pada siklus I kurang memuaskan. Siswa belum terbiasa dengan metode yang digunakan sehingga siswa merasa bingung dan ramai sendiri di kelas. Beberapa siswa juga tidak mau berdiskusi dan hanya mengandalkan salah satu siswa untuk mengerjakan LKS. Pada saat presentasi, siswa kurang memperhatikan teman yang sedang presentasi di depan. Pembelajaran juga kurang optimal karena guru tidak menyampaikan tujuan pembelajaran dan tidak mengarahkan salah satu siswa dalam kelompok untuk menjadi pemimpin diskusi dalam kelompok. Berdasarkan hasil observasi, rata-rata hasil observasi guru mengajar pada siklus I ini adalah $85 \%$, sedangkan rata-rata hasil observasi siswa pada siklus I ini adalah 68,6\% .Tampak bahwa pembelajaran dengan model pembelajaran kooperatif telah adanya 
peningkatan tes kemampuan komunikasi matematika siswa, namun belum sesuai dengan harapan. Hal ini dapat dilihat dari presentase rata-rata tes kemampuan komunikasi dasar yaitu 41,63 menjadi $79,81 \%$ dan 2 dari jumlah siswa yang mencapai ketuntasan menjadi 18 dari jumlah siswa yang telah mencapai ketuntasan setelah diadakan siklus I.

Setelah pelaksanaan tindakan dan analisis data pada siklus I selesai, maka hasil refleksi dari siklus I adalah sebagai berikut:

1) Pada saat proses pembelajaran berlangsung, guru tidak memberikan motivasi kepada siswa

2) Guru tidak mengarahkan siswa untuk merefleksi terhadap kegiatan pembelajaran berlangsung.

3) Siswa terlihat belum terbiasa dengan penerapan model pembelajaran kooperatif, sehingga pada saat guru meminta kepada siswa untuk berkelompok, kondisi kelas menjadi sangat gaduh dan ramai.

4) Tidak semua siswa mengerjakan LKS.

5) Diskusi kelompok belum berjalan dengan baik.

\section{Siklus II}

\section{a. Perencanaan}

Perencanaan yang dilakukan pada dasarnya sama seperti perencanaan pada saat akan melaksanakan siklus 1, hanya pada tahap kedua ini hasil refleksi dari siklus 1 menjadi bahan masukan pada pelaksanaan siklus ini. Yang dipersiapkan meliputi:

1) Rencana pelaksanaan pembelajaran (RPP)

2) LKS matematika dengan submateri

a) Menentukan rumus dan menghitung luas permukaan balok (LKS 1)

b) Menentukan rumus dan menghitung volume balok (LKS 2)

3) Latihan Soal

a) Menentukan rumus dan menghitung luas permukaan balok

b) Menentukan rumus dan menghitung volume balok

4) Soal tes siklus 2

5) Lembar observasi guru.

6) Lembar observasi aktivitas siswa.

\section{b. Pelaksanaan}

Siklus II dalam penelitian ini dilaksanakan dalam tiga kali pertemuan .

1) Pertemuan Pertama Pertemuan pertama dilaksanakan pada hari Selasa tanggal 21 Mei 2013. Pukul 08.20 diawali dengan guru membuka pembelajaran dengan berdoa dan mengucapkan salam. Guru menyampaikan tujuan pembelajaran dan menjelaskan pendekatan pembelajaran yang akan digunakan yaitu dengan menggunakan model pembelajaran kooperatif. Kemudian guru mengingatkan kembali pembagian kelompok dan meminta 
siswa untuk duduk pada kelompoknya masing-masing. Terdapat 5 kelompok dengan 2 kelompok beranggotakan 5 siswa dan 3 kelompok beranggotakan 4 siswa. Guru dan observer membagikan 2 bendel lks 1 kepada setiap kelompok dan diberikan waktu 30 menit. Sebagian besar siswa masih belum berdiskusi dengan teman satu kelompoknya. Masih ada siswa yang ramai di kelas. Guru berkeliling mendorong diskusi antar siswa dalam kelompok dan memberikan arahan serta bimbingan bagi siswa atau kelompok yang mengalami kesulitan dalam menyelesaikan LKS 1. Kegiatan diskusi dilanjutkan hingga masingmasing kelompok dapat membuat membuat pertanyaan, menyimpulkan dan menyelesaikan soalnya. Selanjutnya guru menghentikan kegiatan diskusi dan meminta siswa untuk istirahat. Berikutnya guru mengarahkan siswa untuk mepresentasikan hasil diskusinya. Guru memanggil kelompok 1 untuk mempresentasikan kegiatan 1. Setelah itu guru membahas pekerjaan dari kelompok yang sudah menuliskan hasil diskusi mereka dan meminta pendapat dari kelompok lain, apakah ada pendapat yang berbeda, ternyata semua siswa menjawab tidak ada. Selanjutnya guru memanggil kelompok 2 untuk mempresentasikan kegiatan 2. Setelah itu guru membahas pekerjaan dari kelompok yang sudah menuliskan hasil diskusi mereka dan meminta pendapat dari kelompok lain. Karena kegiatan 1 adalah membuat soal mengenai luas permukaan kubus beserta jawabannya, maka setiap kelompok mempunyai soal dan jawaban yang berbeda-beda. Kemudian guru memanggil kelompok 3 untuk mempresentasikan kegiatan 3 dan membahasnya. Selanjutnya guru memanggil kelompok 4 untuk mepresentasikan dan membahasnya. Ketika pembelajaran berakir guru meminta siswa untuk mempelajari materi selanjutnya kemudian guru menutup pembelajaran dengan berdo'a dan mengucapkan salam.

\section{2) Pertemuan Kedua}

Pertemuan keduaa dilaksanakan pada hari Juma'at tanggal 24 Mei 2013. Pelaksanaan pertemuan kedua ini sama dengan pertemuan kedua.

3) Pertemuan Ketiga

Pertemuan ketiga dilaksanakan pada hari Selasa tanggl 28 Mei 2013. Pertemuan ini merupakan evaluasi dari proses belajar mengajar yang telah dilaksanakan..

\section{c. Pengamatan (Observing)}

1) Data Hasil Observasi Guru

Berdasarkan hasil observasi guru, guru telah melakukan langkahlangkah model pembelajarn kooperatif sesuai dengan harapan. Guru telah berusaha memperbaiki tindakan dalam pembelajaran dengan menyampaikan tujuan pembelajaran dan mengarahkan siswa untuk berlatih menjadi pemimpin 
diskusi. Dengan siswa berlatih menjadi pemimpin diskusi siswa akan belajar mandiri dan belajar mengungkapkan pendapat mereka. Guru juga mengarahkan siswa untuk aktif berdiskusi dengan kelompok sehingga proses pembelajaran berjalan dengan baik dan kondusif

\section{2) Data Hasil Observasi Siswa}

Pengamatan yang dilakukan adalah tiap individu dalam kelompok. Sebagian besar tahapan pembelajaran dalam model pembelajaran kooperatif matematika telah dilakukan dan hanya sebagian kecil siswa yang melakukan kegiatan yang tidak sesuai dengan pembelajaran. Sebagian besar siswa juga telah menunjukkan kegiatan kemampuan komunikasi matematika siswa.

3) Data Catatan Lapangan

Menurut hasil data catatan lapangan sebagian besar siswa sudah terlibat aktif dalam kegiatan kelompok yang dilaksanakan.

\section{4) Data Hasil Wawancara}

Hasil wawancara dengan guru dan siswa menunjukkan bahwa model pembelajaran kooperatif dalam pembelajaran matematika cukup menarik karena dapat membuat variasi dalam pembelajaran, sehingga suasana belajar menjadi tidak membosankan dan monoton. Selain itu, juga dapat membuat siswa untuk berpartisipasi aktif dalam pembelajaran. Dengan menerapkannya model pembelajaran kooperatif ini dapat melatih siswa untuk berani mengungkapkan pendapat mereka sendiri dan juga dapat melatih siswa untuk saling bekerja sama dengan siswa lainnya dalam pembelajaran, sehingga dapat meningkatkan kemampuan komunikasi matematika siswa. Siswa juga berpendapat bahwa dengan penggunaan LKS dapat memudahkan mereka dalam memahami materi karena mereka harus belajar melalui proses pencarian terlebih dahulu dan tidak hanya sekedar menerima teori dari guru.

\section{d. Refleksi}

Dalam tahap ini, peneliti dan guru matematika melakukan refleksi bersama atas tindakan yang telah dilakukan selama siklus II. Masingmasing pihak menyampaikan pendapat dan pandangannya selama tindakan yang dilakukan, yang didasarkan pada pengamatan dan catatan masing-masing. Peneliti dan guru kemudian meninjau kembali apakah ada perubahan aspek yang diamati, seberapa jauh tindakan telah sesuai dengan rencana, dan bagaimana hasilnya.

Berdasarkan hasil pengamatan pada siklus II, pembelajaran dengan menggunakan model pembelajaran kooperatif telah berjalan dengan cukup baik dan sesuai harapan. Hal ini terlihat dari guru telah menyampaikan tujuan pembelajaran sehingga siswa termotivasi dalam belajar. Guru juga 
telah mengarahkan siswa untuk berlatih menjadi pemimpin diskusi dalam setiap kelompok sehingga siswa berlatih untuk mandiri dan lebih berani mengungkapkan ide atau pendapat mereka. Pada siklus II ini, siswa terlihat sudah terbiasa dengan model pembelajaran kooperatif, sehingga pada saat guru meminta kepada siswa untuk berkelompok, kondisi kelas sudah dapat terkendali dengan lebih baik. Proses diskusi kelompok pada siklus II ini sudah berjalan dengan baik karena siswa yang mengalami kesulitan dalam menyelesaikan permasalahan yang ada dalam LKS bertanya terlebih dahulu kepada ketua kelompok atau teman satu kelompoknya sebelum bertanya kepada guru, Guru secara optimal memberikan pengarahan kepada siswa serta telah melaksanakan pembelajaran sesuai dengan Rencana Pelaksanaan Pembelajaran yang telah disusun.

Berdasarkan pedoman dari tahapan pembelajaran kooperatif yang digunakan oleh peneliti, maka pelaksanaan tindakan kelas pada siklus II telah berjalan optimal. Siswa telah ikut berpartisipasi aktif dalam pembelajaran di kelas dan guru telah berperan baik sebagai fasilitator dalam proses pembelajaran. Selain itu, juga sudah terjadi peningkatan kemampuan komunikasi matematika siswa dilihat dari skor nilai tes siklus dan hasil observasi.

Berdasarkan pengamatan, ratarata hasil observasi guru pada siklus II adalah $95 \%$. Dalam hal ini telah terjadi peningkatan aktivitas guru yang pada mulanya rata-rata hasil observasi guru pada siklus I adalah $85 \%$ menjadi $95 \%$. Sedangkan rata-rata hasil observasi siswa pada siklus II adalah $86,9 \%$. Dalam hal ini telah terjadi peningkatan aktivitas guru yang pada mulanya ratarata hasil observasi siswa pada siklus I adalah $68,6 \%$ (kategori cukup) menjadi $86,9 \%$ (kategori tinggi)

Dari tes hasil belajar siswa sudah mengalami peningkatan sesuai dengan apa yang diharapkan. Hal ini dapat dilihat dengan adanya peningkatan rata-rata nilai dari tahaptahap yang telah dilaksanakan yaitu presentase rata-rata tes kemampuan yang semula $41,63 \%$, setelah dilaksanakan siklus I rata-rata meningkat menjadi $79,81 \%$. Setelah dilaksanakannya siklus II rata-rata nilai meningkat menjadi $84,9 \%$. Pada siklus I rata-rata ketuntasan siswa adalah $81,8 \%$. Sedangkan pada siklus II ratarata ketuntasan siswa mengalami peningkatan menjadi 90,9\%. Dari hasil wawancara juga terlihat siswa sangat antusias mengikuti pembelajaran. Berdasarkan uraian-uraian di atas dapat disimpulkan bahwa pembelajaran yang telah dilakukan pada siklus II sudah cukup baik, sehingga siklus tidak perlu dilanjutkan.

\section{KESIMPULAN}


Berdasarkan hasil penelitian dapat disimpulkan bahwa pelaksanaan pembelajaran matematika menggunakan model pembelajaran kooperatif pada materi luas permukaan dan volume kubus, balok di kelas VIIIE SMP Negeri 2 Sedayu dapat meningkatkan kemampuan komunikasi matematika siswa.

\section{Penggunaan}

pembelajaran kooperatif dapat meningkatkan kemampuan komunikasi matematika siswa dari persentase tes kemampuan awal sebesar 41,63\% dengan ketuntasan awal kelas 9\% kemudian pada siklus I persentase ratarata tes kemampuan komunikasi meningkat menjadi $74,81 \%$ dengan ketuntasan kelas menjadi $72,7 \%$. Pada siklus II persentase tes kemampuan komunikasi menjadi $81,8 \%$ dengan ketuntasan menjadi $90,9 \%$ sehingga dapat disimpulkan rata-rata persentase kemampuan komunikasi mengalami peningkatan sebesar $40,17 \%$ dan ketuntasan belajar siswa mengalami kenaikan sebesar $81,9 \%$.

\section{DAFTAR PUSTAKA}

Arikunto, Suharsimi, dkk. 2008. Penelitian Tindakan Kelas. Jakarta: PT Bumi Aksara.

Anita Lie. 2008. Cooperative Learning : Mempratekkan Cooperative Learning Di Ruang-Ruang Kelas. Cetakan ke-IV. Jakarta : Grasindo

Slavin, Robert E. 1995. Cooperative Learning, Second Edition. USA: Allyn and Bacon

Yani Ramdani. 2012. Pengembangan Instrumen dan Bahan Ajar untuk Meningkatkan Kemampuam Komunikasi, Penalaran, dan Koneksi Matematis dalam Konsep Integral. Jurnal FMIPA UNISBA, (online), Vol. 13, No. 1. (http://jurnal.upi.edu/file/6yani ramdhani.pdf, diakses 20 februari 2013) 